vivalists. I hope Noll and Balmer's reflections - in conjunction with Martin's thought-provoking essay - will encourage all readers to raise new questions and gain new insights into the meaning of the history of Iowa and the Midwest.

\title{
Linking Billy Sunday and the Mystique of the Middle West to the Religious History of Iowa
}

\section{MARK A. NOLL}

IN HIS CREATIVE THINK PIECE, Robert Martin argues that it is possible to link the rise and decline of Billy Sunday as a popular revivalist to a parallel rise and decline of the image of the Midwest - from a Progressive, optimistic, dynamic place to one marked by parochialism, insularity, and rural backwardness. Such an argument cannot, of course, be "demonstrated" in any strict sense. But Martin's arguments are especially suggestive at several points - for example, in contending that Sunday's "athleticism, masculinity, and Christianity" resembled virtues praised by the era's political Progressives; or in showing that Sunday's revival message combined traditional themes of Protestant Christianity with more contemporary injunctions about an up-to-date American moralism. There is, thus, some reason to think that the rising tide of popularity that Sunday enjoyed through the First World War should be regarded as a national seal of approval for a Progressive, Protestant, midwestern style and that the descending curve of popularity that Sunday experienced from about 1920 was a sign that this style was going out of favor. For its provocations to think about big ideas and national trends in connection with one flamboyant career, Martin's essay performs a genuine service. But does it do anything specifically for the history of Iowa?

Beyond noting that Sunday was born in Story County, that he lived for a time in an Iowa orphanage, and that he later worked in Nevada and Marshalltown before pursuing his 
public careers as baseball player and revivalist, the essay is short on specifics about Iowa. ${ }^{1}$ Yet a brief look at matters related to Iowa - specifically, to relative population growth and ecclesiastical geography - shows that, while such considerations may complicate Martin's portrait, they also lend it considerable support.

IF MARTIN IS CORRECT that public images of the Midwest and of Billy Sunday were largely. favorable through roughly the First World War and then declined rapidly thereafter, this paired trajectory may have something to do with the demographic vitality of the region. When Billy Sunday emerged from Iowa and then Chicago to national prominence around the turn of the century, he was riding the crest of a midwestern population explosion. By the time Sunday's star had begun to decline, the spectacular growth of the Midwest had reversed to become demographic stagnation. If one can link population curves with public attitudes (that is, rapid increase equals positive public perception, stagnation equals negative perceptions), then the population history of Iowa and the Midwest provides some help in explaining phenomena such as the rise and fall of Billy Sunday's popularity.

Billy Sunday was not shy about referring to his origins. Conceivably, however, salvoes like the following could be received differently depending on the attitude of hearers:

I was bred and born . . . in old Iowa. I am a rube of the rubes. I am a hayseed of the hayseeds, and malodors of the barnyard are on me yet, and it beats Pinaud and Colgate, too. I have greased my hair with goose grease and blacked my boots with stove blacking. I have wiped my old proboscis with a gunny-sack towel; I have drunk coffee out of my saucer and I have eaten with my knife; I have said "done it," when I should have said "did it," and I "have saw" when I should "have seen," and I expect to go

1. Sunday actually lived in two different orphanages, both Soldiers' Orphans homes, one in Glenwood south of Council Bluffs and the other in Davenport. Sunday's stay in the latter was especially important for what he learned there about discipline and religion. See Lyle W. Dorsett, Billy Sunday and the Redemption of Urban America (Grand Rapids, 1991), 10-13. I am grateful to Professor Dorsett for insights gained about Billy Sunday from many conversations. 
to Heaven just the same. I have crept and crawled out from the university of poverty and hard knocks, and have taken post graduate courses. $^{2}$

When the national stock of self-help and gumption was high, such words may have been received more warmly than when those characteristics had come to appear as rustic idiosyncrasies.

Even to posit such grandiose correlations begs a thousand questions. Nonetheless, it is still intriguing to note that the North Central category in the United States census grew much more rapidly than national population precisely between the time of Sunday's birth (1862) and the beginnings of his work as an independent revivalist (1896). Likewise, although Sunday's popularity continued to rise for a few years after population growth in the North Central region began to lag behind the nation, his popularity followed that population curve downward, so that by the time of his death (1935) both Sunday and (if Martin is correct) the Midwest were perceived much less favorably than a generation before. These population trends are even more striking for Sunday's own West North Central region than for the North Central region as a whole (see table).

If the image of Billy Sunday and the perception of the Middle West did in fact follow the paths that Martin described, more particular attention to how rapidly the region was growing, and how variable rates of population growth were perceived, might strengthen the case he has made.

BILLY SUNDAY'S EARLY YEARS in Story, Marshall, and Scott Counties take on possible significance for his later career once those counties are plotted on an ecclesiastical map. Again, real research rather than casual observations would be necessary to demonstrate a connection between Sunday's later popularity and the circumstances of his youth. But Martin's sound observation that Sunday's later popularity had much to do with his ability to mediate between rural and urban values as well as between theology and moralism opens up possibilities for other ways in which Sunday's life may have been a mediation.

2. Quoted in Jacob A. Swisher, "Billy Sunday," Palimpsest 11 (1930), 344-45. 
TABLE

U.S. POPULATION GAINS, 1860-1900 AND 1900-1930

(AS PERCENTAGE)

\begin{tabular}{lcccc}
\hline & U.S. & $\begin{array}{c}\text { North } \\
\text { Central }^{\text {a }}\end{array}$ & $\begin{array}{c}\text { West North } \\
\text { Central }^{\mathrm{b}}\end{array}$ & Iowa \\
\hline $1860-1900$ & 141 & 189 & 377 & 231 \\
$1900-1930$ & 62 & 47 & 29 & 11 \\
\hline
\end{tabular}

SOURCE: Historical Statistics of the United States: Colonial Times to 1957 (Washington, DC, 1960).

"Ohio, Indiana, Illinois, Michigan, Wisconsin, Minnesota, Iowa, Missouri, North Dakota, South Dakota, Nebraska, and Kansas.

bMinnesota, Iowa, Missouri, North Dakota, South Dakota, Nebraska, and Kansas.

For example, Billy Sunday grew up along major fault lines in the ecclesiastical geography of the Midwest. Ecclesiastically considered, the Middle West, at least since the mid-nineteenth century, has been, like Gaul, divided into three parts. Even though there was always a considerable measure of denominational pluralism throughout the region, there were also large areas dominated by particular denominations. In Michigan, the Chicago area and northern Illinois, much of Wisconsin, and the Twin Cities, Roman Catholics have been the largest church since the 1860 s and 1870 s. From roughly the same period, Lutherans of German and Scandinavian extraction have predominated in central and western Wisconsin, much of Minnesota, North Dakota, and eastern South Dakota. Even earlier than Catholic and Lutheran concentration in these areas, Methodists had staked out as their turf a broad band stretching from the East Coast to the Rocky Mountains in what historian Martin Marty once called "the South of the North and the North of the South, the path of the revivalists from Pennsylvania and Virginia west to Colorado. ${ }^{\prime 3}$ Through this mid-section of the nation

3. Martin E. Marty, "The Career of Pluralism in America," in Jackson W. Carroll, Douglas W. Johnson, and Martin E. Marty, Religion in America: 1950 to the Present (San Francisco, 1979), 52. My sense of midwestern religious geography relies on ibid.; Edwin Scott Gaustad, Historical Atlas of Religion in America, rev. ed. (New York, 1976); the county-by-county maps of denominational distribution produced by the Glenmary Research Center (Atlanta, GA); and Historical Statistics. 
in a band ranging from two to three hundred miles wide, Methodists prevailed as the majority religious presence. Their main competition came from evangelical Protestants such as Baptists, Disciples, Christians, Presbyterians, and Congregationalists who shared the Methodists' British evangelical origins.

The relevance of this geography for Billy Sunday's life is that almost from its earliest years as a state Iowa has been a meeting ground for these major religious traditions. Northeastern Iowa, with Dubuque as its largest city, is heavily Catholic; Lutherans predominate over roughly the northern half of the western twothirds of the state; and Methodists have been historically strong over the entire southern half. Of course, there are many local anomalies within this general pattern - with Methodists, for example, strong in the north around Mason City; the Dutch Reformed thick in Marion County and the far northwest; concentrations of Christians, Presbyterians, Congregationalists, and Quakers interspersed among the Methodists in the southern half of the state; and a broader mix of denominations in the major cities. But the general pattern, as well as the large number of smaller denominations that has always seasoned Iowa's areas of Catholic, Lutheran, or Methodist dominance, gives fresh significance to Billy Sunday's Iowa.

Local denominational figures are hard to come by for the early decades of Sunday's life, but Iowa's own detailed census of 1895 - a rare instance of census-takers asking about religious affiliation-reflects a pattern that probably would not have been too different from the years of Sunday's youth. That census shows that Sunday lived right where major denominational blocks intersected. The adjacent Story and Marshall Counties, where he was born, attended high school, worked, and began to play baseball, were square on the line of Lutheran-Methodist division. In Story County, Lutherans were overwhelmingly the largest denomination, but in Marshall County, the Methodists $(2,845)$, followed by Christians $(1,798)$, and Friends $(1,549)$, were much larger than either the Lutherans (748) or the Catholics $(1,219)$. North and west of where Sunday spent his earliest years was Lutheran land, south and southeast Methodist. Scott County, where Sunday spent two important years in an orphanage, represented another fault line, this time between Roman 
Catholics and various Protestant bodies. The 1895 census showed 5,884 Catholic members, 2,510 Methodists, 2,035 Lutherans, 1,814 Presbyterians, and 1,465 Baptists. ${ }^{4}$

These membership figures prepare us to reflect further on Sunday's notorious indifference to denominational labels as a professional evangelist. Although he was himself an ordained Presbyterian minister, he flourished as a nondenominational entrepreneur. It was his magnetism, his message, his methods, his manipulation - or some combination thereof - that made him a dynamic preacher, not his denominational credentials. Iowa, with its strongly multidenominational heritage that Sunday experienced firsthand, may well have nurtured his wellproven ability to mediate among religious groups-and that may have been as significant for his later success as his ability to mediate between small town and city.

To be sure, in the early years of Sunday's career as an itinerant, when he preached often in Iowa, he was most likely to carry on his work in the state's "Methodist belt" across its southern half. In his first fifteen years on the road, before he gained the prominence that moved him to large cities, Sunday held at least twenty-six campaigns in his home state. Apart from a cluster of northern meetings in Garner, Mason City, and Grundy Center (where alongside strong Lutheran or Catholic populations there were also significant numbers of Methodists and related groups), and meetings in Cedar Rapids (1909) and Waterloo (1910) after he had gained more stature, all of Sunday's early Iowa meetings were in Methodist country: Atlantic, Audubon, Bedford (where he preached twice), Exira, and Harlan in the west; Afton, Centerville, Corydon, Jefferson, Knoxville, Leon, Marshalltown, Perry, and Seymour in the central part of

4. The 1895 census recorded 5,657 adults and children as members of Lutheran churches in Story County; the 1,205 Methodists trailed well behind as the next largest church. The total of members is from "members of church" plus "members of Sabbath school" as recorded in Census of Iowa for 1895, 398-425. The only other detailed county-by-county enumerations of Iowa churches and church membership or adherence that I know are Bureau of the Census, Religious Bodies: 1906 (Washington, DC, 1910), 311-14; and Martin B. Bradley, et al., Churches and Church Membership in the United States, 1990 (Atlanta, 1992), 143-55. 
the state; and Burlington, Fairfield, Keokuk, Muscatine, Ottumwa, and Sigourney in the east. ${ }^{5}$

Thus, one should not push too far the ecumenicity of Sunday's early years. But it still may be important as a feature of his Iowa history, as well as a bit of concrete evidence in support of Robert Martin's arguments, that Sunday's later ease in moving among diverse values had something to do with his nurture in regions where denominations coexisted in relative peace.

ROBERT MARTIN poses several significant questions: Can a person (such as Billy Sunday) so embody subjective traits associated with a region (the Middle West) as to rise to national popularity on the strength of that association? Can in fact the reputation of a region constitute a meaningful historical datum so as to be correlated with anything specific at all? Was Billy Sunday an evangelist for a particular set of midwestern values, with a Progressive or late Republican cast? And did his eventual success as an urban revivalist rise from his ability to mediate values that Americans were increasingly viewing as deriving from earlier times and places? These are unusually interesting questions, which Martin's essay poses with unusual force.

To turn such fruitful questions into an agenda for historical research is no easy matter. Tracking broad trends in population and noting large-scale features of ecclesiastical geography may not be the best places to start such real research. But for those who want to take the measure of a region, as well as one of its most famous religious figures, population trends and ecclesiastical geography will probably have to figure in the mix in some way.

5. "Partial List of the Campaigns of William Ashley Sunday," in Robert Shuster, $A$ Guide to the Microfilm Edition of the William and Helen Sunday Papers (Wheaton, IL, 1987), 21-25. This very helpful finding aid shows that, after Sunday transferred his activities from small towns to larger cities, he returned to Iowa only infrequently: Des Moines (1914), Davenport (1919), Sioux City (1921), Des Moines again (1933), and Sioux City again (1934). 
Copyright of Annals of Iowa is the property of State of Iowa, by \& through the State Historical Society of Iowa and its content may not be copied or emailed to multiple sites or posted to a listserv without the copyright holder's express written permission. However, users may print, download, or email articles for individual use. 